\title{
Representasi Gender dalam Folklor Jepang
}

\author{
Nina Alia Ariefa, Mutiawanthi \\ Program Studi Sastra Jepang, Fakultas Sastra, Universitas Al Azhar Indonesia, \\ Komplek Masjid Agung Al Azhar, Jl. Sisingamangaraja Kebayoran Baru, Jakarta 12110 \\ Penulis untuk Korespondensi/E-mail: nina_alia@uai.ac.id
}

\begin{abstract}
Abstrak - Penelitian ini bertujuan untuk menemukan representasi gender dalam folklor Jepang. Data utama dalam penelitian ini adalah sembilan buah cerita rakyat Jepang yang terdiri dari Issunboshi, Tanishi no Shusse, Kaguya Hime, Tsuru no Ongaeshi, Ningyou no Oyomesan, Hito no Yome ni Natta Neko, Harikazuki Hime, Yomesan ni Natta Ichou no Ki no Sei, dan Yome no Jumyou. Pendekatan gender digunakan dalam analisis penelitian ini melalui pengamatan terhadap relasi gender yang terjadi antara tokoh perempuan dan laki-laki. Kesimpulan dari penelitian ini adalah terdapat penggambaran representasi yang berbeda antara tokoh perempuan dan tokoh laki-laki terkait masalah gender yang mencakup perbedaan ruang aktivitas, penggambaran karakter, serta peran/tanggung jawab.
\end{abstract}

Kata Kunci: Gender, Representasi, Folklor Jepang

Abstract - This research aims to discover gender representation in Japanese folklore. The main data are nine Japanese folklores consist of Issun-bōshi, Tanishi no Shusse, Kaguya Hime, Tsuru no Ongaeshi, Ningyou no Oyomesan, Hito no Yome ni Natta Neko, Harikazuki Hime, Yomesan ni Natta Ichou no Ki no Sei, and Yome no Jumyou. Gender approach used to analysis these folklores by observing the gender relation between women and men characters. The results show that there are different representations portrayal related to gender between women and men characters, which depicted from their activities, behaviours, and roles/responsibilities.

Keywords: Gender, Representation, Japanese Folklore

\section{PENDAHULUAN}

$S^{a}$ astra lisan, sebagai bagian dari sastra tradisional, merupakan kekayaan budaya suatu bangsa, dan wujud warisan masa lalu yang berasal dari leluhur. Dalam sastra lisan terkandung muatan kearifan lokal bangsa tersebut, yang berfungsi sebagai refleksi masyarakat penuturnya. Kearifan lokal dapat didefinisikan sebagai suatu kekayaan budaya lokal yang mengandung kebijakan hidup; pandangan hidup (way of life) yang mengakomodasi kebijakan (wisdom) dan kearifan hidup. Kearifan lokal dapat pula dipandang sebagai identitas bangsa yang menuntun masyarakatnya ke dalam pencapaian kemajuan dan keunggulan, etos kerja, serta keseimbangan dan keharmonisan alam dan social. Kearifan local yang terkandung dalam sastra lisan, diajarkan secara turun-temurun, dan diwariskan dari generasi ke generasi, hingga wujudnya tetap ada dan dapat kita rasakan hingga masa kini.

Salah satu yang masuk dalam cakupan sastra lisan di antaranya adalah folklor. Folklor secara umum didefinisikan sebagai bagian dari kebudayaan suatu kolektif yang disebarkan dan diwariskan secara tradisional, baik dalam bentuk lisan maupun contoh yang disertai dengan gerak isyarat atau alat pembantu pengingat (mnemonik device) (Danandjaja, 2002:2). Sebagai bagian dari sastra lisan, folklor memiliki peran dalam penyebaran nilai-nilai kearifan lokal dari kolektif pendukungnya. 
Salah satu kajian yang dapat dilakukan terhadap folklor adalah melalui pendekatan feminisme yang memungkinkan dilakukannya penelaahan terhadap konstruksi gender yang terdapat dalam folklor. Dengan demikian melalui penelitian jenis ini, dapat diperoleh mengenai gambaran konstruksi gender pada suatu masyarakat.

Pendekatan feminisme dalam kajian bidang sastra menitikberatkan pada pemerhatian terhadap tokoh perempuan dalam interaksinya dengan tokoh laki-laki dalam karya sastra. Oleh karena itu, fokus penelitian jenis ini terletak pada analisis mengenai relasi antara perempuan dengan laki-laki. Gambaran atas relasi yang diperoleh tersebut, mengarah pada gambaran gender suatu masyarakat. Penemuan gambaran representasi dalam folklor Jepang inilah yang menjadi tujuan dalam penelitian ini, dengan perumusan masalah sebagai berikut:

(1) Bagaimana representasi gender yang tergambar dalam folklor Jepang?

\section{KERANGKA TEORI DAN TINJAUAN PUSTAKA}

\section{Folklor}

Kata folklor berasal dari bahasa Inggris, yaitu folk dan lore. Menurut Alan Dundes, arti kata folk adalah sekelompok orang yang memiliki ciri-ciri pengenal fisik, sosial dan kebudayaan sehingga dapat dibedakan dari kelompokkelompok sosial lainnya. Sementara itu kata lore berarti tradisi dari folk, yaitu sebagian kebudayaan yang diwariskan secara lisan atau melalui suatu contoh yang disertai dengan gerak isyarat atau alat pembantu pengingat.

Folklor mempunyai empat fungsi. Pertama, folklor sebagai sistem proyeksi, yaitu sebagai alat pencerminan angan-angan suatu kelompok. Kedua, folklor sebagai alat pengesahan pranata-pranata dan lembaga-lembaga kebudayaan. Ketiga, folklor sebagai alat pendidikan anak-anak. Contoh foklor sebagai alat pendidikan adalah foklor lisan (nyanyian anak). Keempat, folklor sebagai alat pemaksa norma agar masyarakat selalu mematuhinya.

\section{Gender}

Istilah 'gender' diperkenalkan oleh para ilmuwan sosial untuk menjelaskan perbedaan perempuan dan laki-laki yang bersifat bawaan sebagai ciptaan Tuhan dan yang bersifat bentukan budaya yang dipelajari dan disosialisasikan sejak kecil. Pembedaan ini sangat penting, karena selama ini sering sekali mencampur-adukkan ciri-ciri manusia yang bersifat kodrati dan yang bersifat bukan kodrati (gender). Perbedaan konsep gender secara sosial telah melahirkan perbedaan peran perempuan dan laki-laki dalam masyarakatnya. Secara umum adanya gender telah melahirkan perbedaan peran, tanggung jawab, fungsi dan bahkan ruang tempat di mana manusia beraktivitas. Sedemikian rupanya perbedaan gender ini melekat pada cara pandang kita, sehingga kita sering lupa seakan-akan hal itu merupakan sesuatu yang permanen dan abadi sebagaimana permanen dan abadinya ciri biologis yang dimiliki oleh perempuan dan laki-laki.

Kata 'gender' dapat diartikan sebagai perbedaan peran, fungsi, status dan tanggungjawab pada laki-laki dan perempuan sebagai hasil dari bentukan (konstruksi) sosial budaya yang tertanam lewat proses sosialisasi dari satu generasi ke generasi berikutnya. Dengan demikian gender adalah hasil kesepakatan antar manusia yang tidak bersifat kodrati. Oleh karenanya gender bervariasi dari satu tempat ke tempat lain dan dari satu waktu ke waktu berikutnya. Gender tidak bersifat kodrati, dapat berubah dan dapat dipertukarkan pada manusia satu ke manusia lainnya tergantung waktu dan budaya setempat.

Pengertian gender juga termasuk membicarakan mengenai relasi gender yang merupakan hubungan sosial antara laki-laki dan perempuan yang dibentuk secara sosial dan budaya dalam melakukan segala hal. Relasi gender juga mencakup bagaimana relasi itu dibangun dan didukung oleh masyarakat. Seperti halnya konsep kelas, ras, dan suku, gender merupakan alat analisis untuk memahami relasi-relasi sosial antara perempuan dan laki-laki. Sampai saat ini, hambatan bagi terwujudnya kesetaraan antara perempuan dan laki-laki lebih banyak disebabkan oleh kesenjangan perempuan dan 
laki-laki yang dikonstruksikan oleh masyarakat. Kesenjangan relasi tersebut dipengaruhi oleh faktor-faktor sejarah, budaya, ekonomi dan agama yang mengakar sangat kuat secara turun temurun di kalangan masyarakat. Kenyataan seperti inilah yang berdampak pada kehidupan perempuan dan laki-laki dalam kehidupan sehari-hari, baik di ranah domestik (rumah tangga) maupun di ranah publik (masyarakat, dunia kerja, dunia pendidikan).

Pada kenyataannya, perbedaan biologis yang ada pada perempuan dan laki-laki digunakan sebagai indikator kepantasan dalam berperilaku, yang akhirnya berujung pada pembatasan hak, akses, partisipasi, kontrol dan menikmati manfaat dari sumberdaya dan informasi. Akhirnya tuntutan peran, tugas, kedudukan dan kewajiban yang pantas dilakukan oleh laki-laki atau perempuan dan yang tidak pantas dilakukan oleh laki-laki atau perempuan sangat bervariasi dari masyarakat satu ke masyarakat lainnya. Ada sebagian masyarakat yang sangat kaku membatasi peran yang pantas dilakukan baik oleh laki-laki maupun perempuan, misalnya tabu bagi seorang laki-laki masuk ke dapur atau mengendong anaknya di depan umum dan tabu bagi seorang perempuan untuk sering keluar rumah untuk bekerja. Namun demikian, ada juga sebagian masyarakat yang fleksibel dalam memperbolehkan laki-laki dan perempuan melakukan aktivitas sehari-hari, misalnya perempuan diperbolehkan bekerja sebagai kuli bangunan sampai naik ke atap rumah atau memanjat pohon kelapa, sedangkan laki-laki sebagian besar menyabung ayam untuk berjudi.

\section{Representasi}

Representasi adalah konsep yang mempunyai beberapa pengertian. Ia adalah proses sosial dari 'representing'. Representasi menunjuk baik pada proses maupun produk dari pemaknaan suatu tanda. Representasi juga bisa berarti proses perubahan konsep-konsep ideologi yang abstrak dalam bentuk-bentuk yang kongkret. Representasi adalah konsep yang digunakan dalam proses sosial pemaknaan melalui sistem penandaan yang tersedia, misalnya dialog, tulisan, video, film, fotografi, dan sebagainya. Secara ringkas, representasi adalah produksi makna melalui bahasa (Hall, 1997:15).

Menurut Stuart Hall (1997), representasi adalah salah satu praktek penting yang memproduksi kebudayaan. Kebudayaan merupakan konsep yang sangat luas, kebudayaan menyangkut 'pengalaman berbagi'. Seseorang dikatakan berasal dari kebudayaan yang sama jika manusia-manusia yang ada disitu membagi pengalaman yang sama, membagi kode-kode kebudayaan yang sama, berbicara dalam 'bahasa' yang sama, dan saling berbagi konsep-konsep yang sama. Bahasa adalah medium yang menjadi perantara dalam memaknai sesuatu, memproduksi dan mengubah makna. Bahasa mempu melakukan semua ini karena ia beroperasi sebagai sistem representasi. Lewat bahasa (simbol-simbol dan tanda tertulis, lisan, atau gambar) dapat mengungkapkan pikiran, konsep, dan ide-ide tentang sesuatu. Makna sesuatu hal sangat tergantung dari cara individu merepresentasikannya. Dengan mengamati kata-kata yang digunakan dan imej-imej yang gunakan dalam merepresentasikan sesuatu bisa terlihat jelas nilai-nilai yang diberikan pada sesuatu hal tersebut.

Untuk menjelaskan bagaimana representasi makna lewat bahasa bekerja, bisa dipakai tiga teori representasi sebagai usaha untuk menjawab pertanyaan: darimana suatu makna berasal, Atau bagaimana individu membedakan antara makna yang sebenarnya dari sesuatu atau suatu imej dari sesuatu. Yang pertama adalah pendekatan reflektif. Di sini bahasa berfungsi sebagai cermin, yang merefleksikan makna yang sebenarnya dari segala sesuatu yang ada di dunia. Kedua adalah pendekatan intensional, dimana manusia menggunakan bahasa untuk mengkomunikasikan sesuatu sesuai dengan cara pandang terhadap sesuatu. Sedangkan yang ketiga adalah pendekatan konstruksionis. Dalam pendekatan ini dipercaya bahwa individu mengkonstruksi makna lewat bahasa yang dipakai.

\section{METODE PENELITIAN}

Penelitian ini merupakan penelitian dengan metode deskriptif analisis. Langkah kerja 
penelitian ini diawali dengan pemilihan sembilan buah cerita rakyat Jepang sebagai corpus penelitian. Pemilihan cerita rakyat dilakukan berdasarkan ada tidaknya tokoh laki-laki dan perempuan dalam cerita tersebut. Langkah berikutnya yaitu proses pengolahan data berupa pembacaan secara terstruktur dari seluruh cerita untuk mendapatkan struktur alur pada masing-masing cerita dan penandaan tokoh yang akan dijadikan fokus dalam analisis. Langkah berikutnya adalah pengamatan terhadap para tokoh dan dilanjutkan dengan penandaan relasi gender. Dari penandaan relasi gender tersebut, dilanjutkan dengan analisis representasi gender, dan pengklasifikasian representasi gender secara menyeluruh. Langkah terakhir dalam penelitian ini yaitu penarikan kesimpulan.

\section{HASIL DAN PEMBAHASAN}

Proses analisis dilakukan dengan menganalisis sembilan buah cerita rakyat Jepang yaitu Issunboshi, Tanishi no Shusse, Kaguya Hime, Tsuru no Ongaeshi, Ningyou no Oyomesan, Hito no Yome ni Natta Neko, Harikazuki Hime, Yomesan ni Natta Ichou no Ki no Sei, dan Yome no Jumyou, berdasarkan struktur alur serta representasi gender pada masing-masing cerita.

\section{Isshunboshi}

Struktur alur pada cerita rakyat Issunboshi terdiri dari 36 tahapan. Tokoh yang yang akan dijadikan fokus dalam analisis adalah ayah dan ibu Issunboshi, Issunboshi dan sang putri, sang putri dengan ayahnya (sang pejabat). Relasi gender tampak pada tokoh ayah dan ibu Issunboshi, pada tokoh Issunboshi dan sang putri, pada tokoh sang putri dan sang pejabat.

\section{Tokoh ayah dan ibu Isshunboshi}

Representasi gender tampak melalui tokoh ayah dan ibu dari Issunboshi dan tergambar pada saat Issunboshi hendak meminta ijin untuk pergi mengadu nasib menuju Kyoto. Kutipannya adalah sebagai berikut:

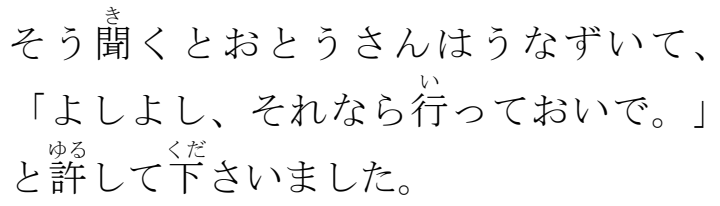

Kutipan di atas memberikan gambaran mengenai peran ayah sebagai pengambil keputusan dalam sebuah keluarga. Sosok ibu Issunboshi tidak muncul berdampingan bersama ayah Isshunboshi dalam peran ini. Sang ibu hanya diceritakan membantu Issunboshi menyiapkan berbagai perlengkapan untuk perjalanannya. Hal ini mengindikasikan adanya suatu pembagian fungsi antara suami dan istri. Sebagai kepala keluarga, seorang suami memiliki peran sebagai pengambil keputusan, sedangkan fungsi istri adalah turut serta dalam mendukung hasil keputusan tersebut, seperti yang dilakukan Ibu Issunboshi dalam menyiapkan segala keperluan Issunboshi. Hal ini juga memberikan gambaran mengenai cakupan tanggung jawab seorang ibu dalam keluarga yaitu dalam hal pengurusan anak.

\section{$\underline{\text { Tokoh Issunboshi dan Putri pejabat }}$}

Dari kisah ini, tampak bahwa tokoh Issunboshi digambarkan sebagai tokoh lelaki yang periang dan penuh percaya diri meski ukuran tubuhnya tidak seukuran lelaki normal seusianya. Selain itu, tokoh ini digambarkan sebagai sosok yang aktif, penuh cita-cita, dan memiliki rencana tentang masa depannya.

$$
\begin{aligned}
& \text { 「京都は天子さまのいらっしやる日本一 } \\
& \text { 此 } \\
& \text { の都ですし、おもしろいしごとがたくさ } \\
& \text { んあります。わたくしはそこへ行って、 } \\
& \text { 運だめしをしてみようと思います。」 }
\end{aligned}
$$

Nasib baik datang menghampiri Issunboshi. Ia dipekerjakan di sebuah rumah pejabat tinggi. Di sana ia bekerja dengan giat sehingga banyak orang yang menyukainya. Salah satunya adalah putri pejabat yang akan berusia 13 tahun. Ia berteman baik dengan Issunboshi, sehingga Issunboshi kerap menemani sang putri kemanapun sang putri bepergian. Representasi gender tampak saat muncul suatu peristiwa saat sang putri dibuang oleh sang ayah keluar dari istana karena suatu kesalahan yang ditimpakan padanya. Saat mereka tiba di 
sebuah pulau yang tak berpenghuni, mereka dihadang oleh dua monster yang mengerikan. Monster itu hendak melahap sang putri, sang putri seketika pingsan karena terkejut. Melihat sang putri pingsan tak berdaya, Issunboshi menghadang si monster dan menghardiknya, sambil menghunuskan pedang jarum miliknya. Meski dilahap oleh sang monster, Issunboshi berusaha untuk melukai bagian dalam tubuh sang monster dengan pedangnya, hingga akhirnya dua monster itu kesakitan dan lari tunggang langgang.

Dari peristiwa ini, terlihat penggambaran perbedaan karakter yang menjadi bagian representasi gender melalui tokoh Issunboshi dan Putri dengan segala daya dan upaya yang dimiliki mereka masing-masing. Tokoh Issunboshi digambarkan sebagai laki-laki yang pemberani, penuh strategi, daya juang tinggi, serta percaya diri. Sedangkan pada tokoh putri, digambarkan sebagai sosok yang tidak berdaya, dan takkan mampu selamat jika tak ada Issunboshi yang menyelamatkannya dari dua monster tersebut. Selain itu, secara general, dari relasi dua tokoh ini, diperoleh gambaran mengenai gender yang melahirkan perbedaan peran, yang berkaitan dengan karakter yaitu karakter aktif yang dilekatkan pada tokoh lakilaki (Issunboshi), dan karakter pasif pada tokoh perempuan (sang putri pejabat).

\section{Tokoh sang putri dan sang pejabat}

Sosok sang putri digambarkan sebagai gadis muda yang cantik. Ia berteman akrab dengan Issunboshi. Ia dibuang oleh ayahnya dari istana karena suatu kesalahan yang tidak ia perbuat, yang sebenarnya direncanakan dan dibuat dengan sengaja oleh Issunboshi. Issunboshi mengerjai sang putri setelah ia kalah dari sang putri saat mereka bertengkar. Issunboshi dengan sengaja menaburkan sisa remah kue di sekitar mulut sang putri yang sedang tertidur pulas, Setelah itu Issunboshi mengadu kepada pejabat bahwa sang putri telah menghabiskan seluruh kue milik Issunboshi yang telah dihadiahkan oleh sang pejabat kepada dirinya.

Atas kesalahan yang tidak ia perbuat, sang putri harus menanggung kemarahan sang ayah dan menerima nasibnya dibuang keluar dari tempat tinggalnya selama ini. Dalam peristiwa tersebut, sang putri sama sekali tidak diceritakan mendapatkan kesempatan untuk dapat berbicara memberikan penjelasan. Sang ayah hanya sepihak mendengarkan keterangan yang dibuat oleh Issunboshi, dan langsung memercayainya ketika ia sendiri melihat secara langsung bukti yang memang sudah dibuat oleh Issunboshi.

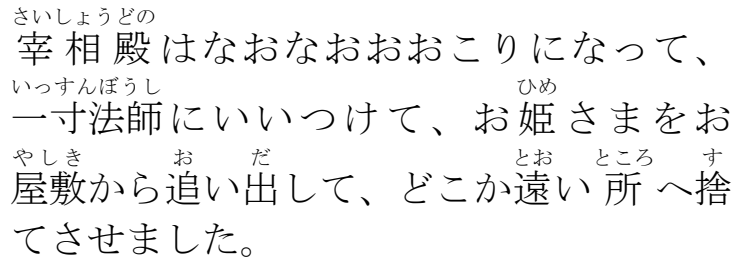

Atas keputusan sang ayah, sang putri dikisahkan menaiki kapal dengan ditemani oleh Issunboshi menuju tempat pembuangannya. Dari relasi dua tokoh ini, diperoleh gambaran mengenai gender yang melahirkan perbedaan peran, yang berkaitan dengan indikator kepantasan yaitu sosok ayah yang mempunyai hak untuk berpendapat dan memutuskan nasib anak perempuannya, sedangkan sosok anak perempuan yang tak mempunyai hak suara di hadapan ayahnya yang memiliki kuasa penuh terhadap dirinya, yang harus patuh atas segala keputusan ayahnya tersebut.

\section{Tokoh Pejabat dengan Istri pejabat}

Pada tokoh istri pejabat, tampak representasi gender berupa peran yang disandang oleh perempuan sebagai ibu. Berikut ini adalah kutipannya.

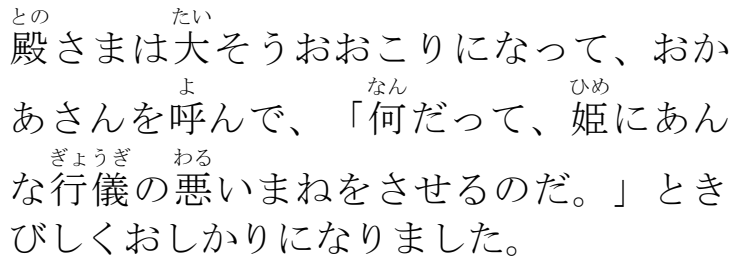

Kutipan di atas menceritakan tentang sikap pejabat yang menumpahkan kemarahannya pada istrinya dan menyalahkan istrinya atas sikap sembrono putri mereka. Dari penggalan tersebut terungkap secara tidak langsung bahwasanya ada pembagian tanggung jawab antara sosok ayah dan ibu dalam keluarga. Hal yang berkaitan dengan pendidikan anak diserahkan kepada sosok seorang ibu. 


\section{Tanishi no Shusse}

Struktur alur pada cerita rakyat Tanishi no Shusse terdiri dari 17 tahapan. Tokoh yang yang akan dijadikan sebagai fokus analisis adalah tokoh putri saudagar dan ayahnya (saudagar), serta tokoh istri siput (putri saudagar) dan suaminya (si siput).

\section{$\underline{\text { Tokoh putri saudagar dan saudagar }}$}

Saudagar kaya menikahkan putrinya dengan siput karena keinginannya untuk dapat memiliki siput ajaib sebagai harta berharga. Berikut ini adalah kutipannya:

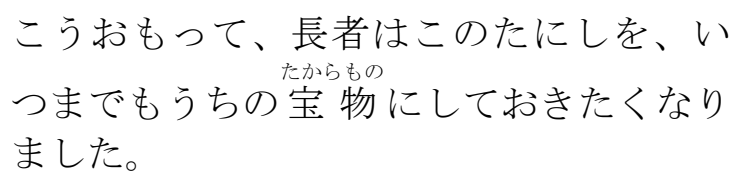

Pada kutipan dialog di atas, demi mencapai keinginannya, saudagar kaya menawari sang siput agar bersedia menikahi putrinya, sehingga sang siput dapat menjadi menantunya. Saudagar kaya memutuskan secara sepihak apa yang akan menjadi nasib putrinya yang harus menikahi sang siput. Berikut ini adalah pertanyaan yang dilontarkan saudagar kepada putrinya:

\section{そこで、こんどは、妹のむすめをよび 出しました。「かわいいたにしどのを、 お前はむこにとりたいか」}

Pada kutipan di atas, meskipun sang saudagar terkesan memberikan kesempatan pada sang putri untuk dapat mengambil keputusannya sendiri, namun sang putri paham bahwa pertanyaan itu merupakan titah bagi dirinya untuk bersedia menikah dengan si siput karena ayahnya kadung berjanji pada siput. Berikut ini kutipannya:

\section{こういうと、妹のむすめは、「おとうさ んのお約束なさったことなら、そのとお りにいたしましょう」と、すなおにこた えたので、とうとう、たにしの子は長者 のむこになることになりました。}

Pada kutipan di atas terlihat bahwa istri siput bersedia menikahi siput karena ia merasa bertanggung jawab atas janji yang telah diucapkan oleh ayahnya. Ia melakukannya sebagai bakti seorang anak kepada ayahnya, karena ia punya kewajiban untuk menjaga nama baik ayahnya. Tidak ada pilihan lain yang tersedia baginya selain melakoni apa yang sudah menjadi peran dan tanggung jawabnya dalam keluarga. Dari relasi dua tokoh ini, diperoleh gambaran mengenai gender yang melahirkan/ perbedaan peran, yang berkaitan dengan tanggung jawab yang diemban oleh seorang anak perempuan terhadap ayahnya dalam sebuah keluarga.

\section{$\underline{\text { Tokoh istri siput dan siput }}$}

Setelah menikah, putri saudagar mengabdi kepada suaminya dan menghormati siput meskipun wujud suaminya sebagai seekor siput, dan meski kedua mertuanya berasal dari kalangan rakyat miskin.

長者のむすめは、たにしのおむこさんを だいじにして、その上、たにしのおとう さんやおかあさんにもしんせつにしてや りました。

Meski istri siput menikah dengan siput demi nama baik ayahnya, namun ia berupaya untuk menjalani tanggung jawabnya sebagai istri yang baik sebagai konsekuensi atas keputusan yang telah ia ambil. Ketulusan dan sikapnya yang penuh pengabdian dan pengorbanan istri siput tampak pada kutipan berikut ini ketika suaminya, si siput, hilang. Ia berusaha mencari siput dengan sungguh-sungguh.

およめさんはよそ行きのきれいな着物が、 どろでよごれるのもわすれて、水田のな かへはいって行きました。

Di akhir cerita ini, dikisahkan bahwa karena ketulusan hati putri saudagar, sang siput berubah wujud menjadi seorang pria yang tampan dan mereka hidup bahagia bersama. Dari relasi dua tokoh ini, diperoleh gambaran mengenai gender yang melahirkan perbedaan peran, yang berkaitan dengan indikator kepantasan dan tanggung jawab perempuan sebagai seorang istri.

\section{Kaguya Hime}

Struktur alur pada cerita rakyat Kaguya Hime terdiri dari 20 tahapan. Tokoh yang yang akan 
dijadikan fokus dalam analisis ini adalah Putri Kaguya (Kaguya Hime) dan para pemuda.

Tokoh utama dalam cerita rakyat ini adalah Kaguya Hime, seorang gadis yang sangat cantik. Karena kecantikannya, ia mendapatkan banyak lamaran dari para pemuda, termasuk dari Kaisar.

でも、かぐやひめは、お嫁に行くつもり はありません。そこでかぐやひめは、困 ってしまい、「では、私が言う品物を持 ってきて下さった方のところへ、お嫁に 行きましょう」と、言って、世にも珍し いと言われる品物を一人一人に頼みまし た。

Dalam kutipan di atas, tokoh Kaguya Hime merasa sungkan untuk menyatakan perasaannya sendiri bahwa ia tidak berminat untuk menikah dengan salah seorang dari pemuda tersebut. Kaguya Hime tidak berani menyatakan penolakannya terhadap lamaran para pemuda tersebut, sehingga ia memilih untuk membuat strategi berupa pengajuan persyaratan yang berat kepada para pemuda tersebut. Dari penggalan ini, diperoleh gambaran mengenai gender yang melahirkan perbedaan peran, mengenai karakter perempuan melalui tokoh Kaguya Hime sebagai sosok perempuan tidak berani untuk mengungkapkan perasaannya secara langsung dan terbuka. Ia tidak mampu mengungkapkan perasaaanya yang sebenarnya terhadap para pemuda tersebut. Sehingga ia harus mencari cara agar dapat menolak pinangan para pemuda tersebut secara tidak langsung.

Gender yang melahirkan indikator kepantasan bagi seorang perempuan secara umum dalam masyarakat, yang cenderung untuk menutupi atau tidak menunjukkan perasaannya, serta tidak mengungkapkan isi hati atau opini pribadinya secara langsung dan terbuka.

\section{Tsuru no Ongaeshi}

Struktur alur pada cerita rakyat Tsuru no Ongaeshi terdiri dari 30 tahapan. Tokoh yang yang akan dijadikan fokus dalam analisis adalah gadis jelmaan burung angsa dan tokoh kakek.
Dari kedua tokoh ini, diperoleh gambaran mengenai gender yang melahirkan perbedaan aktivitas, menyangkut ruang tempat di mana manusia beraktivitas. Berikut ini adalah kutipannya:

ある寒い冬の日、おじいさんは町へたき ぎを売りに出かけました。…あくる朝、 おばあさんが目をさますと、娘はもう起 きて働いていました。いろりには火が然 え、なべからは湯気があがっています。 そればかりか、家中がきれいに掃除され ているのです。

Dari dua kutipan di atas, diperoleh keterangan mengenai ruang aktivitas yang berbeda pada masing-masing tokoh, yaitu kegiatan menjual kayu bakar dan kain tenunan ke kota yang dilakoni oleh tokoh kakek, sedangkan kegiatan memasak, membereskan rumah, dan menenun kain yang dilakukan oleh tokoh gadis jelmaan burung bangau. Penggambaran tersebut mengarah pada perbedaan ruang tempat aktivitas manusia antara laki-laki dan perempuan, dimana terdapat kecenderungan bahwa ruang publik sebagai ruang aktivitas laki-laki dan ruang aktivitas domestik sebagai ruang aktivitas perempuan.

\section{Harikazuki Hime}

Struktur alur pada cerita rakyat Harikazuki Hime terdiri dari 29 tahapan. Tokoh yang yang akan dijadikan fokus dalam analisis adalah tokoh Putri Harikazuki, dan dua tokoh lakilaki, yaitu sang pejabat dan putra pejabat.

Pertemuan pertama antara Putri Harikazuki dan pejabat adalah saat Putri Harikazuki sedang diejek oleh anak-anak kecil karena ia menggunakan mangkuk kayu yang menutupi bagian kepalanya. Karena kasihan, akhirnya seorang pejabat yang saat itu sedang melintasi daerah tersebut bersama rombongannya, membawanya pulang dan mempekerjakannya sebagai wanita yang bertugas di bagian pemandian air panas di kediamannya. Berikut ini kutipannya:

中将は親切な人だったので、鉢かづきを 家に連れて帰ってふろたき女にすること にしました。 
Representasi gender tampak pada pekerjaan tokoh putri Harikazuki, yaitu sebagai pengurus tempat pemandian air panas, yang identik dengan aktifitas kerumahtanggaan (domestik), seperti pada penggambaran kegiatan Putri Harukazuki yang setiap harinya bekerja mengangkat air, dan menyiapkan kayu bakar untuk memanaskan air.

Dari perjalanan hidup Putri Harikazuki, diperoleh penggambaran akan sosok perempuan yang cenderung berkarakter pasif dan berpasrah atas nasibnya. Dimulai saat ia dipaksa oleh ibunya untuk mengenakan mangkuk sebagai penutup kepalanya dan oleh karena itu, sang putri banyak mengalami pengalaman buruk. Ia tidak dapat berbuat apapun atas nasibnya tersebut, hingga akhirnya ia memutuskan untuk melakukan percobaan bunuh diri, meski upayanya tersebut gagal.

Selain itu, penggambaran akan nilai seorang perempuan terlihat pada kutipan dialog berikut ini:

\section{「素晴らしい? 他にはいないだ と？・・・よーし、では嫁合わせをし ようではないか。兄たちの嫁と、あの鉢 かづきを比べようではないか」 三人の 兄の嫁は、とても美しい娘です。}

Pada kutipan dialog antara dua tokoh laki-laki, yaitu sang pejabat dan putranya, meski awalnya ketertarikan putra pejabat kepada Putri Harikazuki dilandasi atas kekagumannya terhadap sifat sabar dan baik hati yang dimiliki oleh sang Putri, namun pada akhirnya yang menjadi tolak ukur dari nilai seorang perempuan adalah kecantikan paras yang dimiliki olehnya. Dialog di atas juga memberikan gambaran mengenai sosok lakilaki yang memiliki kemampuan dalam mengutarakan pendapat dan berani dalam bernegosiasi.

Poin ini berlanjut pada penggambaran perasaan inferior yang dirasakan oleh Putri Harikazuki terhadap kecantikan istri dari masing-masing menantu perempuan pejabat tergambar pada kutipan berikut ini:
「お母さま。観音さま。今夜、嫁合わせ があります。お兄さま方のお嫁さんは、 とても美しい姫君たちと聞きます。わた しの様な鉢から゙きが出て行って、いとお しい若君に恥をかかせるくらいなら、い っそこのままどこかへ・・・」その時で す。

Kutipan di atas memberikan gambaran akan kecemasan yang dirasakan oleh Putri Harikazuki yang tidak ingin mencoreng nama baik sang putra pejabat karena ia merasa parasnya tidak sepadan dengan kecantikan para menantu perempuan sang pejabat.

\section{Yomesan ni Natta Ichou no Ki no Sei}

Struktur alur pada cerita rakyat Yomesan $n i$ Natta Ichou no Ki no Sei terdiri dari 26 tahapan. Tokoh yang yang akan dijadikan fokus analisis adalah tokoh penebang kayu, seorang gadis dan ayah si gadis. Melalui tiga tokoh ini, tampak fungsi dan tanggung jawab dari perempuan dan laki-laki dalam lingkup keluarga. Berikut ini adalah kutipan ceritanya:

すると父親も、この若い木こりが気に入 っていたので、「いいとも。その代わり 娘を、大事にしてくだされよ」と、言っ てくれたのです。「ありがとうございま す」木こりはとても喜び、次の朝、娘さ んを連れて家に帰りました。

Dari kutipan di atas, tergambar bahwa seorang pemuda penebang kayu tertarik dengan seorang gadis dan bermaksud untuk menjadikan gadis tersebut sebagai istrinya. Ia meminta persetujuan dari sang ayah si gadis mengenai hal tersebut. Ayah si gadis yang juga tertarik dengan kepribadian si pemuda, setuju dengan permintaan tersebut, sehingga dikisahkan si gadis menikah dengan si pemuda. Pada kutipan kisah tersebut tampak bahwasanya seorang ayah memiliki keleluasaan dalam mengambil keputusan mengenai pernikahan anak gadisnya. Hal ini mengindikasikan adanya bagian dari tanggung jawab dan fungsi seorang ayah dalam keluarga. Hal ini semakin diperkuat dengan ketiadaan dialog pada tokoh perempuan (anak gadis) yang tidak mengutarakan pendapatnya 
mengenai laki-laki yang akan dinikahinya, sehingga jelas bahwa keputusan pernikahan diputuskan secara sepihak hanya oleh ayah sang gadis. Hal ini menunjukkan indikasi dari representasi seorang perempuan, yaitu sosok pasif yang dilekatkan padanya, serta kepatuhan anak perempuan terhadap ayahnya sebagai bagian dari tanggung jawabnya sebagai anggota keluarga terhadap kepala keluarga. Selain itu, sikap pemuda penebang kayu yang mengajukan pinangan juga diindikasikan sebagai perilaku yang hanya dilakukan oleh laki-laki yang lahir dari perbedaan gender.

Dilihat dari sisi aktivitas para tokoh yang dimunculkan dalam cerita ini, terdapat penggambaran mengenai lingkup kegiatan laki-laki dan perempuan melalui tokoh pemuda penebang kayu dan tokoh si gadis. Pada tokoh pemuda, tergambar aktivitas hariannya sebagai penebang kayu yang kerap mencari kayu hingga ke pelosok gunung. Berikut ini kutipannya:

ある日の事、木こりは今まで行った事が ない山へ行って、道に迷ってしまいまし た。

Dari kutipan tersebut, tampak penggambaran mengenai ruang aktivitas laki-laki yang berada di ruang publik. Sedangkan ruang aktivitas tokoh si gadis terungkap pada kutipan berikut ini:

嫁になった娘さんは、とても気立てが良 くて働き者でした。木こりの母親も、良 い嫁が来てくれたと大喜びです。こうし て、三人の幸せな毎日が過ぎていきまし た。

Sosok gadis yang baik hati dan rajin membuat ibu mertuanya sangat senang dengan kehadiran menantu perempuan barunya dalam rumah mereka. Dan diceritakan selanjutnya bahwa karena kehadiran si gadislah, mereka menjalani keseharian mereka dengan bahagia. Sosok baik hati dan rajin yang dikenakan pada tokoh perempuan menjadi salah satu poin penting yang mengindikasikan adanya pembagian peran yang berhubungan dengan nilai kepantasan dan fungsi yang menyangkut ruang aktivitas yang disematkan pada perempuan. Pembagian peran berdasarkan nilai kepantasan yang dimaksud adalah sifat baik hati dan rajin, sehingga ia dianggap sebagai seorang menantu perempuan yang baik, sedangkan fungsi yang menyangkut ruang aktivitas perempuan yang tampak pada cerita ini adalah mengurus rumah tangga (lingkup domestik).

\section{Ningyo no Oyomesan:}

Struktur alur pada cerita rakyat Ningyou no Oyomesan terdiri dari 22 tahapan. Tokoh yang yang akan dijadikan fokus dalam analisis adalah seorang pemuda miskin dan seorang gadis cantik jelmaan boneka perempuan.

Pada cerita ini, representasi gender tergambar melalui aktivitas antara tokoh laki-laki, yaitu si pemuda miskin dan tokoh perempuan, yaitu si boneka perempuan. Dikisahkan bahwa si pemuda miskin adalah sosok pekerja keras. Ia bekerja di kediaman seorang tuan tanah, sehingga ruang aktivitas yang tergambar melalui tokoh laki-laki ini adalah pada ruang publik. Berikut ini adalah kutipannya:

大変な働き者…ある日の事、若者は長者 の屋敷へ仕事に出かけました。

Dalam keadaan miskin, kemungkinan sang pemuda mendapatkan istri sangatlah kecil. Sadar akan keadaaannya tersebut, sang pemuda memberanikan diri meminjam boneka berwujud anak perempuan sang tuan tanah agar bisa menemaninya di rumahnya, meski hanya sekedar menemaninya makan.

$$
\begin{aligned}
& 「 \cdots そ こ て ゙ 一 \text { 度でいいから、この人形の } \\
& \text { そばでごはんを食べてみたいのです」 }
\end{aligned}
$$

Dari kutipan di atas, tergambar representasi gender mengenai fungsi seorang perempuan. Selain itu, penggambaran ruang aktivitas perempuan juga tergambar saat si boneka perempuan membereskan rumah dan memasak untuk si pemuda. Berikut ini kutipannya:

‥そのうちに人形はかまどに火をつけて、 ごはんをたきはじめました。

Dari beberapa kutipan di atas, diperoleh informasi mengenai representasi gender yang melahirkan perbedaan ruang aktivitas manusia. Aktifitas tokoh laki-laki berada pada ruang 
publik, sedangkan aktifitas tokoh perempuannya berada pada pada ruang domestik.

\section{Hito no Yome ni Natta Neko}

Struktur alur pada cerita rakyat Hito no Yome ni Natta Neko terdiri dari 21 tahapan. Tokoh yang dijadikan fokus dalam analisis adalah seekor kucing betina yang menjelma menjadi seorang gadis cantik dengan seorang pemuda petani miskin.

Hubungan di antara kedua tokoh ini mulanya adalah sebagai seorang tuan dengan binatang peliharaannya. Lalu di akhir cerita keduanya menjadi sepasang suami istri, setelah kucing betina tersebut berubah wujud menjadi seorang gadis cantik. Petani miskin tersebut memberi kasih sayang kepada kucing betina peliharaannya, dan dibalas dengan pengabdian dari si kucing betina kepada tuannya. Interpretasi betina pada kucing mewakili sisi keperempuanan pada cerita ini.

Representasi gender melalui dua tokoh ini melahirkan perbedaan penggambaran tanggung jawab yang diemban oleh masingmasing tokoh dan perbedaan pada ruang tempat aktivitas mereka. Dalam sebuah penggalan cerita ini, dikisahkan bahwa petani miskin berharap seandainya si kucing bisa membantunya menggiling gandum di rumah selagi ia pergi bekerja di ladang. Berikut ini adalah kutipannya:

「もしお前が、人間だったらなあ。おれ が畑へ出ている間に、家で麦の粉をひい てくれたら、どんなに暮らしが楽になる か」

Kutipan di atas memberikan gambaran akan pembagian ruang aktivitas yang dijalani oleh laki-laki dan perempuan. Pekerjaan di ladang merupakan aktivitas yang dikerjakan tokoh laki-laki yang masuk pada kategori aktifitas di ruang publik sebagai bandingan atas kegiatan menggiling gandum yang dikerjakan di rumah oleh kucing betina (gadis cantik) yang merupakan aktivitas domestik.

\section{Musume no Jumyou}

Struktur alur pada cerita rakyat Musume no Jumyou terdiri dari 21 tahapan. Tokoh yang yang akan dijadikan fokus dalam analisis adalah tokoh seorang gadis dan ayahnya.

Pada cerita ini, relasi gender tampak pada tokoh sang anak perempuan (gadis) dengan ayahnya. Kutipannya adalah sebagai berikut:

翌日、父親は教えられた通り娘にお酒を 持たせて、目隠しをしました。そして朝 六時きっかりに、家から東の山にむかっ て歩かせました。

Pada kutipan di atas diperoleh gambaran mengenai peran ayah yang berperan sebagai pengambil keputusan dalam sebuah keluarga. Sang ayahlah yang menanyakan kepada sang biksu hal yang harus dilakukan. Setelah mendengar hal yang harus dilakukan agar sang gadis tidak mati, keesokan harinya sang ayah memerintahkan anak gadisnya untuk melakukan tindakan sesuai dengan informasi yang disampaikan oleh sang biksu. Hal ini mengindikasikan bahwa peran sang anak perempuan (gadis) hanya terbatas pada keikutsertaannya pada apa yang telah diputuskan ayahnya.

Dari pembahasan sembilan cerita rakyat di atas, diperoleh klasifikasi gender antara tokoh perempuan dan tokoh laki-laki, seperti yang tergambar pada tabel berikut ini.

Tabel 1. Klasifikasi Representasi Gender

\begin{tabular}{|c|c|c|}
\hline \multirow[t]{2}{*}{ Cerita } & \multicolumn{2}{|c|}{ Representasi Gender } \\
\hline & Laki-laki & Perempuan \\
\hline $\begin{array}{l}\text { Isshunbos } \\
\text { hi }\end{array}$ & $\begin{array}{ll}\text { - Seorang } \\
\text { ayah } \\
\text { memiliki } \\
\text { peran } \\
\text { sebagai } \\
\text { pengambil } \\
\text { keputusan } \\
\text { tertinggi } \\
\text { dalam } \\
\text { keluarga. } \\
\text { - Seorang } \\
\text { ayah } \\
\text { memiliki } \\
\text { keleluasaan } \\
\text { berpendapa } \\
\mathrm{t} \quad \text { dan }\end{array}$ & $\begin{array}{ll}\text { - Seorang } \\
\text { istri patuh } \\
\text { serta } \\
\text { mendukung } \\
\text { keputusan } \\
\text { suami. } \\
\text { - Seorang ibu } \\
\text { bertanggun } \\
\text { g jawab } \\
\text { dalam } \\
\text { pemenuhan } \\
\text { kebutuhan } \\
\text { anak. } \\
\text { - Seorang ibu } \\
\text { memiliki } \\
\text { tanggung }\end{array}$ \\
\hline
\end{tabular}




\begin{tabular}{|c|c|c|}
\hline & $\begin{array}{l}\text { memutuska } \\
\mathrm{n} \text { nasib } \\
\text { anak } \\
\text { perempuan } \\
\text { nya. } \\
\text { - Pengambar } \\
\text { an karakter } \\
\text { tokoh } \\
\text { Isshunboshi } \\
\text { sebagai } \\
\text { laki-laki } \\
\text { yang aktif, } \\
\text { penuh } \\
\text { rencana, } \\
\text { berani, dan } \\
\text { percaya } \\
\text { diri. } \\
\text { Mampu } \\
\text { memutuska } \\
\text { n jalan } \\
\text { hidupnya } \\
\text { sendiri }\end{array}$ & $\begin{array}{l}\text { jawab } \\
\text { dalam } \\
\text { mengasuh } \\
\text { dan } \\
\text { mendidik } \\
\text { anaknya. } \\
\text { - Penggamba } \\
\text { ran karakter } \\
\text { sang putri } \\
\text { sebagai } \\
\text { perempuan } \\
\text { yang } \\
\text { berada di } \\
\text { bawah } \\
\text { kekuasaan } \\
\text { ayahnya } \\
\text { dan tidak } \\
\text { berkesempa } \\
\text { tan } \\
\text { mengungka } \\
\text { pkan } \\
\text { pandangan } \\
\text { dan } \\
\text { pendapatny } \\
\text { a. } \\
\text { Sosok pasif } \\
\text { yang } \\
\text { eksistensin } \\
\text { ya } \\
\text { tergantung } \\
\text { pada tokoh } \\
\text { lain. }\end{array}$ \\
\hline $\begin{array}{l}\text { Tanishi } \\
\text { no Shusse }\end{array}$ & $\begin{array}{l}\text { - Seorang } \\
\text { ayah dapat } \\
\text { memilihkan } \\
\text { pasangan } \\
\text { hidup bagi } \\
\text { putrinya. } \\
\text { - Penggamba } \\
\text { ran karakter } \\
\text { sebagai } \\
\text { sosok yang } \\
\text { aktif dalam } \\
\text { menyampai } \\
\text { kan } \\
\text { pandangan }\end{array}$ & 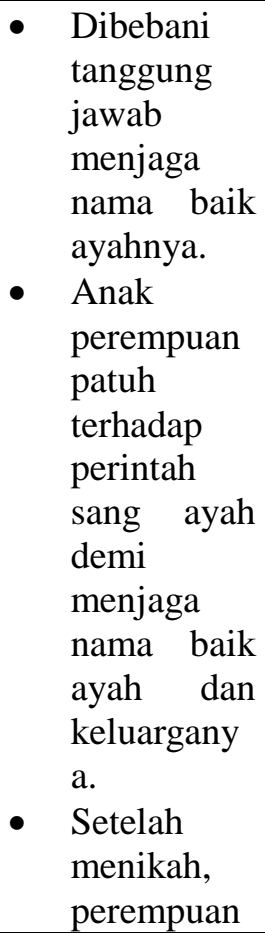 \\
\hline
\end{tabular}

\begin{tabular}{|c|c|c|}
\hline & & $\begin{array}{l}\text { mengabdi } \\
\text { dan } \\
\text { menghorma } \\
\text { ti } \\
\text { suaminya. }\end{array}$ \\
\hline $\begin{array}{l}\text { Kaguya } \\
\text { Hime }\end{array}$ & $\begin{array}{l}\text { - Leluasa } \\
\text { dalam } \\
\text { menyampai } \\
\text { kan } \\
\text { keinginann } \\
\text { ya secara } \\
\text { terbuka }\end{array}$ & $\begin{array}{ll}\text { - } & \text { Tidak } \\
\text { memiliki } \\
\text { keleluasaan } \\
\text { dalam } \\
\text { mengungka } \\
\text { pkan } \\
\text { perasaan, } \\
\text { maupun } \\
\text { pendapat } \\
\text { pribadinya, } \\
\text { ataupun } \\
\text { melakukan } \\
\text { penolakann } \\
\text { ya secara } \\
\text { langsung } \\
\text { dan } \\
\text { terbuka. } \\
\text { Sosok } \\
\text { dengan } \\
\text { karakter } \\
\text { pasrah } \\
\text { terhadap } \\
\text { takdirnya. }\end{array}$ \\
\hline $\begin{array}{l}\text { Tsuru no } \\
\text { Ongaeshi }\end{array}$ & 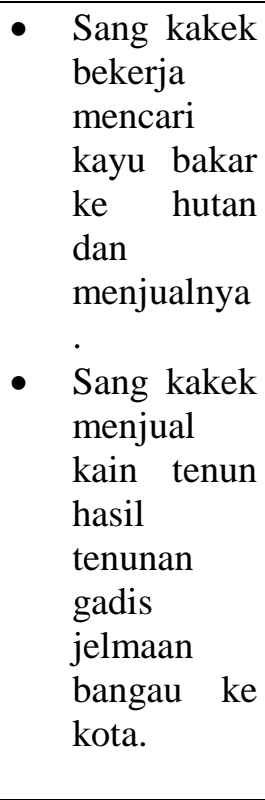 & $\begin{array}{l}\text { - Sang nenek } \\
\text { dan gadis } \\
\text { jelmaan } \\
\text { burung } \\
\text { bangau } \\
\text { mengerjaka } \\
\text { n pekerjaan } \\
\text { rumah, } \\
\text { seperti } \\
\text { memasak, } \\
\text { dan } \\
\text { memberesk } \\
\text { an rumah. } \\
\text { Gadis } \\
\text { jelmaan } \\
\text { bangau } \\
\text { menenun } \\
\text { kain. }\end{array}$ \\
\hline $\begin{array}{l}\text { Harikazu } \\
\text { ki Hime }\end{array}$ & $\begin{array}{ll}\text { - } & \text { Tokoh } \\
\text { pejabat } \\
\text { memiliki } \\
\text { kekuasaan } \\
\text { dan leluasa } \\
\text { dalam }\end{array}$ & $\begin{array}{l}\text { Putri } \\
\text { Harikazuki } \\
\text { bekerja } \\
\text { sebagai } \\
\text { perempuan } \\
\text { pembersih }\end{array}$ \\
\hline
\end{tabular}




\begin{tabular}{|c|c|c|}
\hline & $\begin{array}{l}\text { memutuska } \\
\mathrm{n} \text { sesuatu. } \\
\text { Tokoh anak } \\
\text { pejabat } \\
\text { dapat } \\
\text { menyampai } \\
\text { kan } \\
\text { keinginann } \\
\text { ya secara } \\
\text { terbuka } \\
\text { pada } \\
\text { pejabat } \\
\text { untuk } \\
\text { menikahi } \\
\text { Putri } \\
\text { Harikazuki. }\end{array}$ & $\begin{array}{l}\text { di tempat } \\
\text { pemandian } \\
\text { air panas } \\
\text { yang } \\
\text { bertugas } \\
\text { mengangka } \\
\mathrm{t} \text { air dan } \\
\text { menyiapka } \\
\mathrm{n} \text { kayu } \\
\text { bakar untuk } \\
\text { memanaska } \\
\text { n air. } \\
\text { Sosok } \\
\text { pasrah dan } \\
\text { pasif yang } \\
\text { eksistensin } \\
\text { ya } \\
\text { tergantung } \\
\text { dari tokoh } \\
\text { lain. }\end{array}$ \\
\hline $\begin{array}{l}\text { Yomesan } \\
\text { ni Natta } \\
\text { Ichou no } \\
\text { Ki no Sei }\end{array}$ & $\begin{array}{l}\text { - Sang ayah } \\
\text { dapat } \\
\text { menentuka } \\
\text { n pasangan } \\
\text { hidup bagi } \\
\text { anak } \\
\text { gadisnya. } \\
\text { - Sang } \\
\text { pemuda } \\
\text { bekerja } \\
\text { sebagai } \\
\text { penebang } \\
\text { kayu. }\end{array}$ & 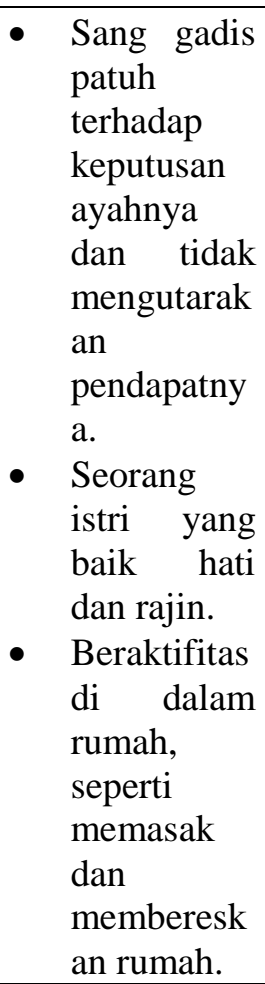 \\
\hline $\begin{array}{l}\text { Ningyo } \\
\text { no } \\
\text { Oyomesa } \\
n\end{array}$ & 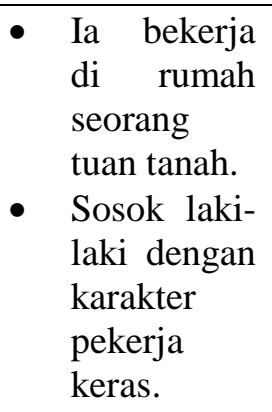 & $\begin{array}{l}\text { Melakukan } \\
\text { kegiatan } \\
\text { seperti } \\
\text { memberesk } \\
\text { an rumah } \\
\text { dan } \\
\text { memasak. }\end{array}$ \\
\hline Hito & - Bekerja di & - Seekor \\
\hline
\end{tabular}

\begin{tabular}{|c|c|c|}
\hline $\begin{array}{ll}\text { Yome } & n i \\
\text { Natta } & \\
\text { Neko } & \end{array}$ & ladang & $\begin{array}{l}\text { kucing } \\
\text { betina yang } \\
\text { menjelma } \\
\text { menjadi } \\
\text { gadis cantik } \\
\text { yang } \\
\text { mengerjaka } \\
\text { n kegiatan } \\
\text { menggiling } \\
\text { gandum } \\
\text { dan } \\
\text { melakukan } \\
\text { pekerjaan } \\
\text { rumah } \\
\text { tangga } \\
\text { lainnya. } \\
\text { Sosok } \\
\text { dengan } \\
\text { karakter } \\
\text { penuh } \\
\text { pengabdian } \\
\text { kepada } \\
\text { suaminya, } \\
\text { dan rajin } \\
\text { bekerja } \\
\text { mengerjaka } \\
\text { n pekerjaan } \\
\text { rumah } \\
\text { tangga dan } \\
\text { ladang. }\end{array}$ \\
\hline $\begin{array}{l}\text { Musume } \\
\text { no } \\
\text { Jumyou }\end{array}$ & $\begin{array}{l}\text { Tokoh ayah } \\
\text { sehari-hari } \\
\text { bekerja di } \\
\text { ladang. } \\
\text { - Sang ayah } \\
\text { berperan } \\
\text { sebagai } \\
\text { pengambil } \\
\text { keputusan } \\
\text { dalam } \\
\text { keluarga. }\end{array}$ & 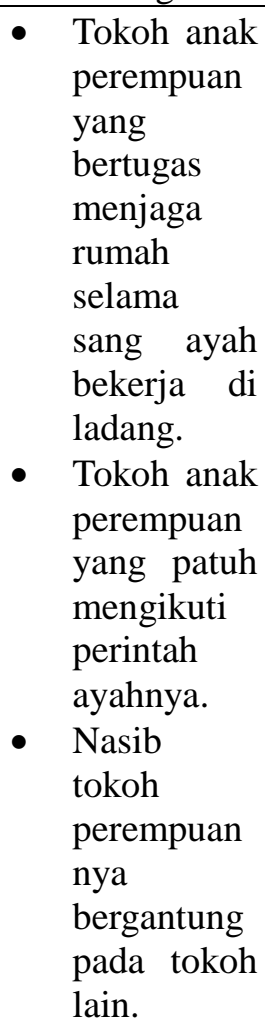 \\
\hline
\end{tabular}




\section{KESIMPULAN DAN SARAN}

Dari analisis terhadap sembilan cerita rakyat Jepang, diperoleh kesimpulan bahwa terdapat penggambaran representasi yang berbeda antara tokoh perempuan dan tokoh laki-laki terkait masalah gender yang mencakup perbedaan ruang aktivitas, penggambaran karakter, serta peran/tanggung jawab.

Pada ruang aktivitas, diperoleh penggambaran bahwa tokoh perempuan beraktivitas di lingkungan rumah tangga (domestik) dengan melakukan kegiatan seperti menenun, memasak, membersihkan rumah, membesarkan dan mendidik anak. Pada beberapa cerita, kegiatan luar rumah yang dilakukan oleh tokoh perempuan terbatas pada pekerjaan di ladang. Sedangkan para tokoh laki-laki dikisahkan beraktivitas di lingkungan publik, seperti menebang kayu, menjual barang ke kota, merantau, dan mengolah sawah/ladang.

Kemudian pada tataran karakter, tokoh perempuan tergambar sebagai sosok yang cenderung pasif, patuh, dan eksistensinya tergantung pada tokoh lain. Selain itu, tokoh perempuan tidak memiliki keberanian serta keleluasaan dalam mengutarakan pendapat, opini, serta perasaan pribadinya secara terbuka. Sedangkan pada tokoh laki-laki, secara umum tergambar sebagai sosok yang aktif dan terbuka dalam menyampaikan pandangan dan keinginannya.

Dalam lingkup keluarga, tokoh laki-laki memiliki peran sebagai kepala keluarga yang berkedudukan lebih tinggi dibandingkan dengan tokoh perempuan. Tokoh laki-laki digambarkan memiliki otoritas dalam mengambil keputusan bagi seluruh anggota keluarga. Sedangkan peran dan tanggung jawab perempuan ada pada lingkup pengurusan rumah tangga, mendidik, membesarkan anak, serta mengabdikan diri mereka pada tokoh laki-laki sebagai bagian dari nilai kepatutan.

\section{UCAPAN TERIMA KASIH}

Ucapan terima kasih penulis tujukan kepada LP2M Universitas Al Azhar Indonesia (UAI) yang telah memberikan dukungan dalam penelitian ini berupa Research Grant dalam Hibah Internal Penelitian tahun anggaran 2015-2016.

\section{DAFTAR ACUAN/PUSTAKA}

[1] Danandjaja, James. Folklor Indonesia: Ilmu Gosip, Dongeng, dan Lain-lain, Grafiti, Jakarta, p.2, 2002.

[2] Endraswara, Suwardi, Metodologi Penelitian Folklor, Media Pressindo, Yogyakarta, p.70, 2009.

[3] Hall, Stuart, Representation: Cultural Representation and Signifying Practices, Sage Publications, London, p.15, 1997.

[4] Ratna, Nyoman Kutha. Penelitian Sastra: Teori, Metode, dan Teknik, Pustaka Pelajar, Yogyakarta, p.45, 2004.

[5] Sugihastuti dan Suharto, Kritik Sastra Feminis: Teori dan Aplikasinya, Pustaka Pelajar, Yogyakarta, p.86, 2005.

[6] Taum, Yoseph Yapi, Studi Sastra Lisan: Sejarah, Teori, Metode, dan Pendekatan Disertai Contoh Penerapannya, Lamamera, Yogyakarta, p.8, 2011.

[7] Tong, Rosemarie P. Feminist Thought: Pengantar Paling Komprehensif kepada Arus Utama Pemikiran Feminis terjemahan oleh Aquarini P. Prabasmoro, Jalasutra, Yogyakarta, p.36, 2009.

[8] Wellek, Rene, and Austin Warren, Theory of Literature, Penguin, Harmondsworth, p., 1976.

[9] http://www.aozora.gr.jp/index pages/pers on329.html [diakses pada tanggal 20 November 2015]

[10] http://hukumusume.com/douwa/pc/minwa iitiran/sougou.html [diakses pada tanggal 25 November 2015 